\title{
Helicobacter rappini
}

National Cancer Institute

\section{Source}

National Cancer Institute. Helicobacter rappini. NCI Thesaurus. Code C86440.

A non-taxonomic grouping of microaerophilic, Gram negative, spindle shaped bacteria assigned to the phylum Proteobacteria and the genus Helicobacter. These organisms are motile by bipolar, sheathed flag ella and are composed of ten species of Helicobacter organisms including the species $\mathrm{H}$. bilis and $\mathrm{H}$. trogontum. Helicobacter rappini are pathogenic, causing abortion in animals and diarrheal symptoms in humans. 